Retail Logistics in the UK: Past, Present and Future

John Fernie*

School of Management \&Languages

Heriot -Watt University

Edinburgh

Ed14 4AS

Leigh Sparks

Institute for Retail Studies

Stirling Management School

University of Stirling

Stirling

FK9 4LA

Alan C McKinnon

School of Management \& Languages

Heriot - Watt University

Edinburgh

EH14 4AS

* Contact author ; j.fernie@hw.ac.uk 


\section{Retail Logistics in the UK: Past, Present and Future}

Key words: retail logistics, UK, grocery, fashion, etail-logistics, sustainability

Paper Type: General Review

Purpose: The purpose of this paper is to provide an overview of the logistical transformation of British retailing over the last three decades and to discuss likely challenges that face logistics managers in the future

Design/Approach: Reviews the key works on retail logistics, including the research undertaken by the authors over the last 20 years.

Findings: Illustrates how retailers have control of the supply chain in the UK drawing upon examples from both the grocery and fashion sectors. Challenges for the future include macro-environment issues such as climate change and recession in addition to improvements in existing in operations with regard to e-fulfilment and implementation of technologies such as RFID.

Originality/Value: This paper provides one of the few contributions to appraise the research undertaken on retail logistics in the UK over the last 20-30 years 


\section{Retail Logistics in the UK: Past, Present and Future}

\section{Introduction}

In the late 1990s, Leigh Sparks wrote that there had been a 'logistical transformation' of British retailing in the previous decade (Sparks, 1998). At the same time John Fernie provided a review of these logistical changes, commenting that the key challenges for the future were those in relation to political, environmental and technological change (Fernie, 1997). The British Government had imposed a brake on out of town shopping developments, and along with environmental groups was seeking to improve recycling of waste and reduce 'food miles' in the supply chain. Concurrently the dot.com boom was producing forecasts of home shopping sales in Europe to account for up to $25 \%$ of overall sales (Mandeville, 2000). Fernie (1997) noted that logistics managers faced new challenges in the Millennium although the pace of change would be difficult to predict. Together John Fernie and Leigh Sparks have produced 3 editions of Logistics \& Retail Management since the late 1990s; each edition has involved a considerable re-write to accommodate changes in the retail supply chain (Fernie and Sparks, 1998, 2004, 2009).

The purpose of this paper is to shed light on the 'logistical transformation' of British retailing during the last three decades. The paper discusses the key logistics concepts and their application to the retail supply chain, prior to dealing more specifically with changes both in the grocery supply chain and fashion logistics. A section is then devoted to the development of etail logistics before 
finally, a discussion of likely challenges that logistics managers will face in the future is provided.

\section{Retail Logistics and Supply Chain Transformation}

Retailers were once the passive recipients of products, allocated to stores by manufacturers in anticipation of demand. Today, retailers are the controllers of product supply in reaction to known customer demand. They control, organise and manage the supply chain from production to consumption. This is the essence of the retail logistics and supply chain transformation that has taken place during the last 20 to 30 years.

In 1996 Alan McKinnon reviewed and summarised the key components required for this retail logistics transformation. He identified six closely related and mutually reinforcing trends:

1. Increased control over secondary distribution: retailers have increased their control over secondary distribution (ie warehouse to shop) by channelling an increasing proportion of their supplies through distribution centres (DCs). In some sectors such as food this process is now virtually complete. British retailers exert much tighter control over the supply chain than their counterparts in many other countries. Their logistical operations are heavily dependent on information technology (IT), particularly the large integrated stock replenishment systems that control the movement and storage of an enormous number of separate products. 
2. Restructured logistical systems: retailers have reduced inventory and generally improved efficiency through for example the development of 'composite distribution' (the distribution of mixed temperature items through the same distribution centre and on the same vehicle) and centralisation in specialist warehouses of slower moving stock. In the case of mixed retail businesses the establishment of 'common stock rooms' (where stock is shared across a number of stores, with demand deciding to which store stock is allocated) is developed.

3. Adoption of 'Quick Response' (QR): the aim has been to cut inventory levels and improve the speed of product flow. This has involved reducing order lead-time and moving to a more frequent delivery of smaller consignments both internally (between DC and shop) and externally (between supplier and DC). This has greatly increased both the rate of stock-turn and the amount of product being 'cross-docked', rather than stored at DCs. QR was made possible by the development of EDI (Electronic Data Interchange) and EPOS (Electronic Point of Sale), the latter driving the 'Sales Based Ordering' (SBO) systems that most of the larger retailers have installed. For example, as an item is sold and scanned in a shop, the data are used to inform replenishment and reordering systems and thus react quickly to demand. Sharing such data with key suppliers further integrates production with the supply function. Major British retailers have been faster to adopt these technologies than 
their counterparts in other European countries, though they still have to diffuse to many small retail businesses.

4. Rationalisation of primary distribution (i.e. factory to warehouse): partly as a result of $\mathrm{QR}$ pressures and partly as a result of intensifying competition, retailers have extended their control upstream of the DC (i.e. from the DC to the manufacturer). In an effort to improve the utilisation of their logistical assets, many have integrated their secondary and primary distribution operations and run them as a single 'network system'. This reduces waste and improves efficiency.

5. Increased return flow of packaged material and handling equipment for recycling/re-use: retailers have become much more heavily involved in this 'reverse logistics' operation. This trend has been reinforced by the introduction of the EU packaging directive. Although the United Kingdom currently lags behind other European countries, particularly Germany, in this field, there remain opportunities to develop new forms of re-usable container and new reverse logistics systems to manage their circulation.

6. Introduction of Supply Chain Management (SCM) and Efficient Consumer Response (ECR): having improved the efficiency of their own logistics operations, many retailers have begun to collaborate closely with suppliers to maximise the efficiency of the retail supply chain as a whole. SCM (and within this, ECR) provide a management framework within which retailers and suppliers can more effectively co-ordinate their 
activities. The underpinning technologies for SCM and ECR have been well established in the United Kingdom, so conditions have been ripe for such developments.

It is clear that many of these trends identified by McKinnon (1996) have been the focus for retailers in the intervening decade or so. Issues such as primary distribution and factory gate pricing, consolidation centres and stockless depots and Collaborative Planning Forecasting and Replenishment (CPFR) have occupied much attention. The overall focus in retail logistics has been altered from an emphasis on the functional aspects of moving products to an integrative approach that attempts to develop end-to-end supply chains. This outcome is normally referred to as supply chain management.

\section{Supply Chain Management}

The roots of supply chain management are often attributed to Peter Drucker and his seminal 1962 article on "the economy's dark continent". At this time he was discussing distribution as one of the key areas of business where major efficiency gains could be achieved and costs saved. Then, and through the next two decades, the supply chain was still viewed as a series of disparate functions (Langley 1986). Once the functions began to be integrated and considered as a supply chain rather than separately, several key themes emerged:

(a) a shift from a push to a pull, ie. a demand, driven supply chain.

(b) customers gaining more power in the marketing channel. 
(c) an enhanced role of information systems to gain better control of the supply chain.

(d) the elimination of unnecessary inventory in the supply chain.

(e) a focus upon core capabilities and increased outsourcing of noncore activities to specialists.

To achieve maximum effectiveness of supply chains, it became clear that integration ie. the linking together of previously separated activities within a single system was required. Companies have had therefore to review their internal organisation to eliminate duplication and ensure that total costs can be reduced, rather than allow separate functions to control their costs in a suboptimal manner. Similarly, supply chain integration can be achieved by establishing on-going relationships with trading partners throughout the supply chain.

In industrial markets supply chain integration focused upon the changes promulgated by the processes involved in improving efficiencies in manufacturing. Total quality management, business process re-engineering and continuous improvement brought Japanese business thinking to western manufacturing operations. The implementation of these practices was popularised by Womack et al's (1990) book "The Machine that Changed the World" which focused on supply systems and buyer-seller relationships in car manufacturing. In a retail context it is claimed that food retailers such as Tesco have increasingly embraced such lean principles for parts of their business (eg Jones 2002). The update by Womack and Jones (2005) of the state of 'Lean 
Solutions' puts retailing (or at least some retailers) at the heart of the changes underway.

During the 1990s this focus on so-called "lean production" was challenged in the US and UK, because of an over reliance on efficiency measures ("lean") rather than innovative ("agile") responses. Agility as a concept was developed in the US in response to the Japanese success in lean production. Agility plays to US strengths of entrepreneurship and information systems technology. An agile supply chain is highly responsive to market demand (Christopher 2000). Harrison et al (1999) argue that the improvements in the use of information technology to capture 'real time' data means less reliance on forecasts and creates a virtual supply chain between trading partners. By sharing information, process integration takes place between partners who focus upon their core competencies. The final link in the agile supply chain is the network where a confederation of partners structure, co-ordinate and manage relationships to meet customer needs (Aldridge and Harrison 2000).

Both approaches of course have their proponents. There is however no reason why supply systems may not be a combination of both lean and agile approaches, with each used when most appropriate (the so-called 'leagile' approach - MasonJones et al 2000, Naylor et al 2002, Towill and Christopher 2002, Bruce et al, 2004). Table 1 provides a summary comparison of lean, agile and leagile supply chains (Agarwal et al 2006). It can be seen that they all have value in particular circumstances.

INSERT TABLE 1 HERE 
It can be suggested that the key concepts within Supply Chain Management include the value chain, resource-based theory of the firm, transaction cost economics and network theory. The thrust of all these concepts is the obtaining of competitive advantage through managing the supply chain (ie within and beyond the single firm) more effectively. They all explore possible benefits of a pan-firm orientation. The aim for retailers (and their supply partners) is to manage this chain to create value for the customer at an acceptable cost. The managing of this so called 'pipeline' has been a key challenge for logistics professionals, especially with the realisation that the reduction of time not only reduces costs, but also gives competitive advantage.

According to Christopher and Peck (2003) there are three dimensions to timebased competition that must be managed effectively if an organisation is going to be responsive to market changes. These are:

- time to market: the speed at bringing a business opportunity to market

- time to serve: the speed at meeting a customer's order

- time to react: the speed at adjusting output to volatile responses in demand.

Christopher and Peck (2003) use these principles to develop strategies for strategic lead-time management. By understanding the lead times of the integrated web of suppliers necessary to manufacture a product, they argue that a 'pipeline map' can be drawn to represent each stage in the supply chain process from raw materials to customer. In these maps it is useful to differentiate between 'horizontal' and 'vertical' time: 
- Horizontal time is time spent on processes such as manufacture, assembly, in-transit or order processing;

- Vertical time is the time when nothing is happening, no value is added but only cost and products/materials are standing as inventory.

It was in fashion markets that this notion of 'time based competition' had most significance, in view of the short time window for changing styles. In addition, the prominent trend in the last decades of the twentieth century has been to source products globally, often in low cost Pacific Rim nations, which lengthened the physical supply chain pipeline. Time has thus become a critical factor to manage with competing tendencies of fashion and supply time. These factors combine to illustrate the trade-offs that have to be made in supply chain management and suggested an imperative to develop closer working relationships with supply chain partners, whether local or distant. Zara is the classic retail example of this "fast fashion" (Bhardwaj and Fairhurst 2010). At the core of such approaches is not only the concept of time, but ideas about visibility (Barrett and Oke 2007) and minimizing and managing disruptions in the supply chain (Oke and Gopalakrishnan 2009).

Walters and Rainbird (2004) conclude that if companies focus too much on the cost implications of supply chain management, then they over emphasise cost efficiency at the expense of meeting consumer demands (ie. the service dimensions). As supply chains have become complex webs and networks with tiers of suppliers to be managed then the business tendency to manage this complexity is to focus on cost efficiency. Walters and Rainbird (2004) argue that firms will be better placed if they 
combine their supply chain capabilities with demand-chain effectiveness. They suggest that demand-chains, which focus on demand, customers and markets and current and potential products and services are vital for businesses, including retailers. As Table 2 suggests there are differences between supply and demand chain processes and approaches. Others might argue that effective and efficient supply chains by definition include demand-chain considerations. Walters (2006a, 2006b) presses the demand chain argument, whilst Canever et al (2008) provides an example of the approach. All recognise the links between supply and demand chain concepts. Here we intend supply chain management to mean incorporating a demand orientation and balance, and to include appropriate lean and agile principles. We illustrate these approaches and the logistics transformation on which they are based below, through examples from the grocery and fashion sectors.

INSERT TABLE 2 HERE

\section{The Grocery Retail Supply Chain in the UK}

The development of supply chain management and the consequent implementation of relationship initiatives have been identified as the fourth and final stage of the evolution of grocery logistics in the UK (Fernie et al 2000). This relationship stage relates to a more collaborative approach to supply chain management after decades of confrontation. The UK is often mooted to have the most efficient grocery supply chain in the world, forming a key contributor to the success and profit margins of its grocery retailers.

This logistical transformation of UK retailing has occurred in a short period of time (Sparks 1998). In the first stage of evolution (pre-1980) the dominant 
method of distribution to stores was by manufacturers that stored products at their factories or field warehouses for multiple drops to numerous small shops. As the retail multiples gained in prominence retailers invested in regional distribution centres to consolidate deliveries from suppliers for onward delivery to stores. This was the first step change in the supply of FMCGs in that buying and distribution became a headquarter function in retailing and the logistical infrastructure created a market for third party logistics service providers.

To all intents and purposes, this change marked the removal of suppliers from control of the supply chain and reinforced the power position at the retailer end of the channel. This period of centralisation throughout the 1980s enabled retailers to reduce lead times, minimise inventory and give greater product availability to customers in their stores. The 1990s witnessed a consolidation of this process. In many cases inventory had only been shifted from store to RDC. By implementing JIT principles, retailers began to focus on their primary distribution networks (from supplier to RDC) demanding more frequent deliveries of smaller quantities. Clearly this created a problem for many suppliers in that they could not deliver full vehicle loads of product. To ensure that vehicle utilisation could be maximised, consolidation centres were created upstream of the RDC. Additionally, retailers have established supplier collection programmes to pick up products from suppliers' factories on return trips from stores. 
In the first part of this century, retail networks have continued to be upgraded as ECR initiatives were enacted and grocery retailers accommodated the increase in non-food products through their distribution centres. Furthermore, the greater sharing of information, especially through internet exchanges, fostered collaborative planning, forecasting and replenishment (CPFR) initiatives to reduce supply chain response times.

It should be stressed that UK grocery retail logistics is relatively distinctive. Retailers not only control the supply chain but also have taken over marketing responsibilities that were once the sole domain of the manufacturer, e.g. product development, branding, advertising and distribution. The high level of retail product brand penetration has enabled them to build up store loyalty and diversify into other businesses such as banking. Control of channels is a way of life for such companies.

In other countries a more fragmented store offering is apparent and different store choice attributes are evident. For example, price and promotions are key drivers of consumer choice in the US, Germany and France when compared with the UK. This means the consumer buys in bulk and the retailer 'forward buys' promotional stock that needs to be housed in distribution centres. Of course, in these markets land and property costs are relatively low compared with the UK, so that the savings in buying costs can outweigh the additional logistics costs. When Safeway (prior to the takeover by Morrisons in 2004) in the UK adopted a 
high/low promotional strategy in order to compete with Asda (Wal-Mart), this led to significant disruption and changes in the operation of its RDC network.

It is also true that not all British grocery retailers have had a smooth ride when it comes to their supply systems. There is little doubt that Tesco has led the way (Sparks 1986, Smith 2006, Smith and Sparks 1993, 2004, 2009) and that their success has put pressure on their competitors. This pressure has been felt in directly competitive ways and also in terms of perceptions of supply chains. As Tesco constantly upgraded its supply chain, others struggled to catch up. Asda endured a transformative period as Wal-Mart systems were introduced. Morrisons had to spend a lot of time and effort on getting the merger with Safeway managed successfully, including logistical integration. Perhaps most dramatically, Sainsbury (having led the market in logistics terms in the $1960 / 70$ s, but then rather failing to invest in the $1980 / 90$ s) decided to go for an advanced technical and technological re-organisation of its supply chain. This "leap" had disastrous consequences. Out of Stocks (OOS) and poor On Shelf Availability (OSA) led to customer dissatisfaction and loss of market share. The company has taken much of the second half of the 2000s to recover its position in the market; much of this recovery was based on a return to more traditional logistics handling systems and approaches. Although a cause célèbre in the trade and academic literature (see Fernie and Sparks, 2009, Zentes et al, 2007 and Fernie and Grant, 2008), O0S/OSA was an industry wide area of concern with IGD /ECR UK monitoring OSA levels and creating industry sub-groups to 
investigate causes and management action to address the issue. O0S however remains an issue both practically and academically (Aastrup and Kotzab 2010).

\section{Fashion Logistics in the UK}

Much of the research on retail logistics has focused upon food/grocery retailing (Fernie and Grant, 2008; Fernie and Sparks, 1998, 2009; Grant and Fernie, 2008), due to the dominance and power position of food retailers in the UK market. For fashion retailers, the process has evolved differently, mainly due to the differing nature of fashion markets. Christopher et al (2004) and Fernie and Sparks (2009) identify four characteristics of fashion markets;

1. Short life cycles - products are designed to represent a period in time or trend, and this is getting shorter;

2. High volatility - trends gain and lose popularity due to forces outside the control of fashion retailers, for example the influence of celebrity;

3. Low predictability - high volatility naturally decreases the ability to forecast sales;

4. High level of impulse purchasing. - consumers place high hedonic value to fashion goods and therefore there is an instant need to purchase it.

An additional characteristic in fashion retail is overseas sourcing; "globalisation of the textile and clothing supply chain is currently intensifying, with many companies sourcing components from overseas," (Jones, 2002 as cited by Bruce et al, 2004, p. 155). This has contributed to the success of retailers such as Zara, 
H\&M, New Look, Matalan and including some of the grocery retailers, notably George at Asda, who emerged as strong entrants into the UK fashion market in the 1990s (Barnes and Lea-Greenwood, 2006). The increased level of threat from these retailers forced other UK retailers (e.g. previous market leader Marks and Spencer) to focus their attention on cost and find ways to decrease cost price. The natural reaction to this has been for retailers to move production to countries with low labour costs (Bruce et al, 2004); "This resulted in extensive and complex apparel supply chains, and consequentially, to long lead times for fashion product due to the large geographical distance between sourcing and selling markets," (Barnes and Lea-Greenwood, 2006, p. 260). However, fashion retailers consider the cost price benefits of off shore sourcing to be of greater concern than the negative impact on lead time (Fernie and Azuma, 2004).

Christopher et al (2004) argue that the combination of all of these characteristics has impacted upon the way in which the logistics process has evolved for fashion retailers. For example, the achievement of quick response is of paramount importance (Bruce et al, 2004). Quick response was developed in the USA in the mid 1980s (Birtwistle et al, 2003; Cooper et al, 1997; Fernie, 1994; Fiorito et al, 1995, Lowson et al 1999), partly as a result of Kurt Salmon Associates estimating that inefficiencies in the US supply chain were losing companies approximately \$25 billion each year (Barnes and Lea-Greenwood, 2006; Birtwistle et al, 2003; Fernie, 2006). The factors causing such huge losses included the amount of time between ordering a product and receiving it and the consequent disruptions between sales, order, receipts, restocking etc (Birtwistle et al, 2003). 
Quick response strategies were developed in an attempt to speed up the time that it took for raw materials to be processed into finished goods. Quick response has been defined as, "a consumer driven business strategy of co-operative planning by supply chain partners ... using IT and flexible manufacturing to eliminate inefficiencies from the entire supply chain," (McMichael et al., 2000, p. 613). Quite simply quick response is a process by which suppliers and retailers develop mutually beneficial and long term relationships in order to reduce lead times and forecasting errors (Fiorito et al, 1995; Forza and Vinelli, 1997). Barnes and Lea-Greenwood (2006), Birtwistle et al (2003) and Fernie (2006) have used the Spanish fashion retailer Zara as an example of a vertically integrated retailer using quick response methods. Zara only commits up to 20 per cent of their buying budget six months in advance of the season with commitment increasing to 50 per cent by the start of the season (Birtwistle et al, 2003). This affords Zara flexibility for the remaining 50 per cent of their budget, allowing the company to react to the latest fashion trends. The result being the allocation of new stock to stores every two weeks, encouraging more frequent visits from customers. The whole business is demand driven and the response time from design to product in store can be as little as twenty one days (Morrell, 2001, Burt et al 2006).

Strong supplier relationships and technology are not the sole factors that underpin the achievement of quick response. Additional supply chain factors can also contribute to a reduction in lead times and forecasting errors, both important elements when striving for quick response. Bruce et al (2004) argue that a supply chain that implements agility will reduce lead times and achieve quick response. However the textiles and clothing industry does not necessarily 
neatly fit into either a lean or agile paradigm. A third hybrid supply chain approach has thus emerged in which inventory is held in some generic or modular form and the final assembly or configuration is only completed when the precise customer requirement is known (Christopher and Towill, 2001). The method of postponement of the production of finished product implies that retailers can source large quantities of generic products from low cost countries and modify them closer to the market when exact demand has been recorded. The questions for the retailer are over the exact choice of products to treat in this way and the location of the postponement (or de-coupling) point in the chain and on the ground. There is also a need for excellent data systems and dissemination and the ability to finish products quickly.

\section{The Challenge of E-tail logistics}

At the outset of this paper it was mentioned that in the 1990s a dot.com boom was envisaged, but that the nature of home shopping and the logistical infrastructure to support such growth was unclear. At that time TV shopping was often mooted to be the likely channel to dominate the e-commerce market. This has not occurred and the over-optimistic forecasts of e-commerce sales were erroneously linked to consumer acceptance of internet purchasing and retailing. Global usage of the internet of course has grown significantly in the first decade of the $21^{\text {st }}$ century. In the UK there are estimated to be 46.7 million users which represents a penetration rate of 76.6\% (Miniwatts Marketing Group, 2010). The slow growth of retail sales online in the late 1990s and early 2000s can be attributed to the use of the internet for informational rather than transactional purposes. Concerns over site security and the initial difficulties in navigating 
sites deterred potential consumers. Also the internet presence of 'bricks and mortar' retailers was limited and conservative in nature because of a fear of cannabalising their traditional store sales. However this has now changed and eretailing has developed more widespread acceptance (see Williams 2009 for a review of the evolution of e-tailing).

In recent years, as the innovation took off, there has been a steady increase in online sales, at a time when recession has impacted upon high street shopping. Whilst some figures of online retail sales should be treated with caution in that some consultancies group digital delivered goods, e.g. bank transactions, airline tickets etc as retail sales, other estimates such as those from Verdict Research deal only with physical products and may be more representative. An indication of the growth in sales is given by Verdict (2008), which show that the UK market has grown from $£ 362$ million in 1998 ( $0.2 \%$ of retail expenditure) to $£ 19.5$ billion in 2008 (6.7\% of retail sales).

Forecasts of the growth of online retail sales are invariably demand-driven and assume that it will be possible to deliver orders to the home at a cost and service standard home shoppers will find acceptable. This is a bold assumption. Over the past decade many e-tail businesses have failed primarily because of an inability to provide cost-effective order fulfilment.

The greatest logistical challenges probably face companies that provide a grocery delivery service to the home. They must typically pick an order 
comprising 60-80 items across three temperature regimes from a total range of 10-25,000 products within 12-24 hours for delivery to customers within 1-2 hour time-slots. For example, Tesco is currently picking and delivering an average of 250,000 such orders every week. New logistical techniques have had to be devised to support e-grocery retailing on this scale. Online shopping for non-food items has demanded less logistical innovation. Catalogue mail order companies have had long experience of delivering a broad range of merchandise to the home, while some major High Street retailers have traditionally made home delivery a key element in their service offering. Online shopping is, nevertheless, imposing new logistical requirements. First, it is substantially increasing the volume of goods that must be handled, creating the need for new distribution centres and larger vehicle fleets. Second, many online retailers are serving customers from different socio-economic backgrounds from the traditional mail order shopper. As they live in different neighbourhoods, the geographical pattern of home delivery is changing. Third, online shoppers typically have high logistical expectations, demanding rapid and reliable delivery at convenient times (Xing and Grant, 2006).

The distribution of non-grocery items however normally exhibits the following differing characteristics:

1. They are generally supplied directly to the home from the point of production or a central distribution centre. Each order comprises a small number of items (often just one) and the order picking is centralised at a national or regional level. A large proportion of the orders are channelled through the 'hub-and-spoke' networks of large parcel carriers or mail order companies. 
2. Within these types of delivery networks, each order must be individually packaged at the central distribution point. This not only increases the volume of packaging in the supply chain: it also takes up more space on vehicles in both the forward and reverse channels.

3. Within home shopping systems, whether catalogue- or Internet-based, there is a large flow of returned product. Typically, around $30 \%$ of non-food products delivered to the home are returned to e-tailers (in contrast to 6$10 \%$ for 'bricks and mortar' retailers) (Nairn, 2003). This requires a major reverse logistics operation comprising the retrieval, checking, repackaging and redistribution of returned merchandise.

4. Because of this large volume of returned product, considerable effort has to be made in rapid "refurbishment" of the returned product to ensure it is quickly available for re-sale on-line.

Wide fluctuations in online demand for particular products, particularly newly released items, can cause the flow of freight through home delivery channels to surge. This was illustrated by the distribution of new Harry Potter books through the Amazon.com networks to arrive on the doorsteps of tens of thousands of households on the day of publication.

\section{Distribution of Online Grocery Sales}

In contrast to the average general merchandise order, which comprises 1-3 separate items, the average online grocery order contains 60-80 items, many of which are perishable and need rapid picking and delivery. This requires localised order picking either in an existing shop or a dedicated fulfilment / pick 
centre. Over the past few years there has been much discussion of the relative merits of store-based or fulfilment centre picking.

The main advantage of store-based fulfilment is that it minimises the amount of speculative investment in new logistical facilities for which future demand is uncertain. Webvan, for example, was planning to build a network of 26 new automated warehouses, at a cost of approximately $\$ 35$ million each, to provide egrocery delivery across the US. Fewer than half of these warehouses were set up before the company went bankrupt in 2001. As a 'pure-player' in the e-grocery market, Webvan did not have an established chain of retail outlets and would have had to form an alliance with an existing retailer to adopt the store-based model. Several British supermarket chains, such as Sainsbury, ASDA and Somerfield, as 'bricks and clicks' retailers, had the option of pursuing store-based or pick-centre fulfilment and opted initially for the latter. Tesco, by contrast, opted for the store-based model. Their experience is described below.

Basing home delivery operations at existing shops allows retailers to improve the utilisation of their existing assets and resources. Retail property can be used more intensively and staff shared between the store and online operations. It is possible to pool retail inventory between conventional and online markets, improving the ratio of inventory to sales. This also gives online shoppers access to the full range of products available in a supermarket to which most of them will be accustomed. 
Another major benefit of shop-based fulfilment is that it enables the retailer to achieve a rapid rate of geographical expansion, securing market share and winning customer loyalty much more quickly than competitors committed to the fulfilment centre model.

On the negative side, however, integrating conventional and online retailing operations in existing shops can impair the standard of service for both groups of customer. The online shopper is disadvantaged by not having access to a dedicated inventory. Although a particular product may be available on the shelf when the online order is placed, it is possible that by the time the picking operation gets underway 'conventional' shoppers may have purchased all the available stock. Where these in-store customers encounter a 'stock-out' they can decide themselves what alternative products to buy, if any. Online shoppers, on the other hand, rely on the retailer to make suitable substitutions. Substitution rates are reckoned to be significantly higher for store-based fulfilment systems than e-grocers operating separate pick centres. For example, Ocado, the only UK e-grocery to rely solely on a pick-centre, claims that it can achieve substitution rates of less than $5 \%$, whereas customers using its store-based competitors sometimes experience substitution rates more than twice this level (McClellan, 2003). In comparing substitution rates, however, allowance must be made for differences in product range. Ocado's range of around 12,500 products is less than half that of the major supermarket chains engaged in online shopping.

Doubts have been expressed about the long-term sustainability of store-based fulfilment. As the volume of online sales expands, conflicts between 
conventional and online retailing are likely to intensify. At the 'front end' of the shop, aisles may become increasingly crowded with staff picking orders for online customers. In practice, however, much of the picking of high-selling lines is done in the back store-room. It is at the 'back-end' that space pressures may become most acute. Over the past twenty years the trend has been for retailers to reduce the amount of back storage space in shops as in-store inventory levels have dropped and quick-response replenishment become the norm. This now limits the capacity of existing retail outlets to support the online order fulfilment operation. New shops can, nevertheless, be purpose-built to integrate conventional retailing and online fulfilment. The Dutch retailer Ahold has coined the term 'wareroom' to describe a dedicated pick facility co-located with a conventional supermarket (Mees, 2000).

Most of the purpose-built fulfilment centres so far constructed are on separate sites. They offer a number of logistical advantages over store-based picking. As their inventory is dedicated to the online service, home shoppers can check product availability at the time of ordering and, if necessary, alter their shopping list. The order picking function should also be faster and more efficient in fulfilment centres as they are specially designed for the multiple-picking of online orders.

To be cost-effective, dedicated pick centres must handle a large throughput. The threshold level of throughput required for viability also depends on the breadth of the product range. It is very costly to offer an extensive range in the early stages of an e-tailing operation when sales volumes are low. Offering a limited 
range can cut the cost of the operation but make it more difficult to lure consumers from conventional retailing. Another inventory-related problem which retailers using pick centres have encountered is the difficulty of disposing of excess stocks of short-shelf life product. When over-stocking occurs in a shop, consumer demand can be stimulated at short notice using price reductions or instore merchandising techniques. It is more difficult using electronic media to clear excess inventory of fresh produce from fulfilment centres that consumers never visit.

Several studies have argued that store-based fulfilment is more appropriate in the early stages of a retailer's entry into the e-grocery market (e.g. Fraunhofer Institute, 2002). It represents a low risk strategy and allows new business to be won at a relatively low marginal cost. As the volume of online sales grows, however, the cost and service benefits of picking orders in a dedicated centre steadily increase until this becomes the more competitive option. Several breakeven analyses have been conducted to estimate the threshold online sales volume at which the fulfilment centre model is likely to be superior. Tesco appears to have reached this threshold volume in the South East of England. In 2006 it opened its first dedicated fulfilment centre in south London, known as a 'Tesco-com only store', because it has a similar format to a conventional shop but is used solely for the picking of online orders. It has subsequently opened 2 other dot.com stores at Aylesford in Kent and Greenford in London with plans to open 10 in total in areas of high population density. (Retail Week, March 12, 2010). The viability threshold for such dedicated operations will vary from retailer to retailer depending on the size and layout of shops, the nature of the 
upstream distribution system, the product range and the customer base. It will also be highly sensitive to the allocation of retail overheads between the conventional and online shopping operations.

A further complicating factor is the geography of the retail market. The relative efficiency of the two types of fulfilment is likely to vary with the density of demand and level of local competition in different parts of the country. In a mature e-grocery market, dedicated pick centres may serve the conurbations, while store-based distribution remains the most cost effective means of supplying the rural hinterlands. The US e-grocer Peapod has a policy of using store-based fulfilment when penetrating new local markets, working in collaboration with retail chains. Once volumes have reached an adequate level, as in Chicago and San Francisco, the company has invested in 'distribution centres'.

Experience in the UK suggests that most new entrants to the e-grocery market opted for the fulfilment model prematurely. Sainsbury, Somerfield and ASDA all set up pick centres and closed them down within a few years. It is now generally acknowledged that at the present level of e-grocery sales in the UK, the storebased distribution model, pioneered by Tesco, is the most cost effective. By supplying orders mainly from its existing shops Tesco dominates the UK internet grocery market, is developing similar businesses amongst its international portfolio and has established itself as the world's largest online grocery retailer (and probably its most profitable). 
The Last Mile Problem

In making the final delivery to the home, companies must strike an acceptable and profitable balance between customer convenience, distribution cost and security. Most customers would like deliveries to be made urgently at a precise time with $100 \%$ reliability. This would minimise waiting time and the inconvenience of having to stay at home to receive the order. Few customers would be willing to pay the high cost of time-definite delivery, however.

The relationship between the width of home delivery 'windows' and transport costs has been modelled for the London area by Nockold (2002). Expanding the window from 180 minutes to 225 minutes and 360 minutes was found to cut transport costs by, respectively, 6-12\% and 17-24\%. Eliminating the time constraint completely yielded cost savings of up to a third. Similar research undertaken in Helsinki has indicated that transport cost savings of 40-60\% are possible where carriers can deliver at any time during the 24 hour day (Punakivi and Tanskanen, 2002). Such flexibility can usually only be achieved where a system of 'unattended delivery' is available. It is estimated that around 50-60\% of UK households have no-one at home during the working day. An average of $12 \%$ of home deliveries in the UK then fail because there is no-one there to receive the goods, imposing a direct cost on carriers of approximately $£ 682$ million in 2006 and causing considerable inconvenience to online shoppers (IMRG, 2006). A good deal of creative thinking has been applied to this problem. 
Figure 1 provides a classification of the main forms of unattended delivery that have so far been developed (McKinnon and Tallam, 2003). A fundamental distinction exists between unsecured and secured delivery. Unsecured delivery, sometimes called 'doorstepping' in the UK, involves simply leaving the consignment outside the house, preferably in a concealed location. This eliminates the need for a return journey and can be convenient for customers, but obviously exposes the order to the risk of theft or damage.

\section{INSERT FIGURE 1 HERE}

When no-one is at home, the delivery can be secured in four ways:

1. Giving the delivery driver internal access to the home or an outbuilding

2. Placing the order at a home-based reception (or 'drop') box:

3. Leaving it at a local collection point

4. Delivering the order to a local agency which stores it and delivers it when the customer is at home

To date, there has been very limited investment in home reception facilities. Many of the companies marketing innovative solutions to the last mile problem have gone out of business, while others have redirected their attention to the faster growing and more lucrative B2B market for the unattended delivery of shop orders, spare parts and catalogues. Investment in a fixed box at an individual home can only be justified at present where the customer makes regular use of an e-grocery service. The volume of non-food product being delivered to the home is still much too low to make such an investment 
worthwhile for the average household. It was estimated in 2003 that only around 22 packages were delivered annually to the average household in the UK (Foley et al., 2003).

It is likely that, for the foreseeable future, CDPs strategically located in or around retail outlets, transport terminals and petrol stations offer the best prospects of commercial viability. They appear to strike a reasonable balance between the conflicting demands of customer convenience, delivery efficiency and security. They can also integrate flows of B2C and B2B orders to achieve an adequate level of throughput.

\section{Future Challenges}

The main trade associations associated with retail supply chains (CIES, CILT, IGD, ECRUK) invariably undertake 'top of the mind 'surveys of their membership to draw up a list of the key challenges facing logisticians in the future, for example, Auton's 2005 survey of CILT members of the key issues of the day. In many ways the topics were fairly similar across most of the forums and conferences. So throughout the 2000s much management attention was devoted to factory gate pricing, including global sourcing, on shelf availability and the implementation of technologies such as RFID. In our book we acknowledged the importance of these issues with contributed chapters on these themes (Fernie and Sparks, 2009). To some extent, however, many issues cited tend to be operational rather than strategic in nature so we felt that over-riding challenges were those relating to e-commerce and sustainability. In addition, the credit crunch and subsequent 
recession put additional pressure on managers to achieve efficiency gains. We have discussed e-commerce challenges at some length in the previous section and focus here on efficiency, transparency, flexibility and sustainability.

(a) Efficiency: The last few years has witnessed an unprecedented downturn in the economy after a decade of exceptional growth. Although a minor recovery is possible in 2010 , the negativity surrounding economies generally make it difficult not to focus on efficiency in its broadest sense. The fluctuating price of fuel and the collapse of the pound have led to rises in prices of many products at a time when disposable income is being severely constrained. As a consequence, demand is slackening and altering. If demand is less volatile and weakening then it could be argued that efficiency could be less of a concern. However, the vast increase in the cost of transporting products makes efficiency absolutely vital. If money can be saved by better load-fill or cleaner driving or by not having so many voids or errors, then the overall effect will be beneficial.

For retailers therefore there are now even more good reasons to be concerned with efficiency. It would seem unlikely that cost pressures are going to diminish in the near future, and whilst consumer confidence and spending may return, being as efficient as possible does not seem like a bad strategy. So it is likely that there will be enhanced pressure to smooth flows as much as possible, to ensure as full a vehicle fill as can be achieved and to make sure that products are in their 'correct' places. Modernisation of equipment and systems and training of staff will be important to ensure efficiency can be gained/delivered. Many of the 
likely developments will be focused on specific issues generating incremental improvements with rapid pay-back.

(b) Transparency: A corollary of efficiency to some degree is the ability to generate transparency in the supply chain, for both internal and external stakeholders. If a supply chain is transparent then it is likely that it can be made more efficient. The more visible that the activities and the products/equipment are in the supply chain, then the more likely it is that mistakes or errors will be avoided and/or problems can be dealt with as they occur. In essence enhanced transparency has the potential to provide a more efficient and effective supply system and to improve availability.

Transparency has a number of dimensions, but increasingly technology is providing the means to improve clarity. However there also has to be the willingness to allow transparency to occur across the supply chain. RFID is a pertinent example here. It has the potential to make supply chains more transparent (though at some cost), but the real benefits seem to derive at two levels; within a business and within the supply chain. If the data from RFID are not shared then true improvements from the knowledge and transparency will be much more scarce.

There is another dimensions to transparency, which has arisen in particular from the increasing interest in internet sales. As internet usage has expanded so the pressures on retailers have increased through their 
need to be truly multi-channel. For example the increasing amount of "click and collect" style approaches, where the consumer reserves a product online and then drops down to the store to collect it, has made the requirement of a real-time stock holding system across all channels a necessity.

For retailers there is also a consideration of the scope and scale of transparency. Is it appropriate to treat all suppliers the same? Can this really be achieved and managed? Or is the real benefit from focusing attention on selected partners and ensuring they can deliver what is needed? In the short term cost pressures could drive transactional priorities, but partnership-based transparency is likely to provide more benefits in the long term.

(c) Flexibility: As with debates about lean and agile, there is a sense in which too much focus on efficiency from a cost point of view can tie retailers into situations that are undesirable in a volatile world. When the recession hit in the UK in late 2008 , some retailers got into trouble not because they could not sell products, but because they were unable to switch off their pipeline of supply quickly enough. Retailers are increasingly going to have to consider more flexible arrangements in all their logistical activities.

(d) Sustainability: Probably the most fundamental change in recent years has been the recognition that supply chains and logistics are critically important in terms of green logistics and sustainability (McKinnon 2006). 
The global issue of climate change has become so important generally that it has forced governments and businesses to consider anew practices and operations that had become entrenched. Climate change has direct effects on logistics and supply practices in many ways, but primarily it has meant that the ideas of green logistics and sustainable distribution have emerged as practical business concerns rather than fringe operational worries (Evans et al 2009).

As climate change has focused concern it has been overlaid by other concerns such as food security. There are clear links here to sustainability and the issues raised may cause some re-thinking about what can and cannot be achieved in this regard. It is still too early to be certain about the evidence in many areas of these topics. The debates about the wisdom or otherwise of biofuels and the difficulties of totally accurate life-cycle analysis are practical illustrations of the problems. At a macrolevel the debates about the style and impact of some local production as opposed to the benefits of production for developing countries, also hint at the difficulties in this area. What seems to be certain is that all practices are being challenged by the new realities. What is less clear is what the best practices are to meet the new demands and/or how we transition between these states of activities. In some cases it might be possible to see small scale changes having major impacts (eg. packaging reduction) but it might also be the case that radical rethinking and transformation of activities might be required (eg. the abandonment of air freight). 
The impacts of many logistics and supply chain practices are going to come under harsh scrutiny at many levels. The cost and environmental impact of road transport or air freight are examples where serious questions will be asked about their sustainability. If costing regimes force businesses to internalise environmental impact costs, then the viability of such behaviour will be questioned. What will be important however, and likely to become even more important, are questions of efficiency. It will make no sense to anyone to send lorries on long distance journeys half full. It will possibly even become morally impossible. As such the aspects of efficiency and transparency will be used to meet the problems thrown up by sustainability.

There will of course be many dimensions to sustainability. A critical aspect in the use of resources will be the need for retailers to reduce packaging and other handling inputs and to enable re-use and re-cycling of packaging, product and other components. Retailers will increasingly have to demonstrate not only that they have done all they can to minimise such impacts but also that they have done all they can to maximise consumer opportunities in recycling. McKinnon and Edwards (2009) have produced an analytical framework (Figure 2) to illustrate the measures that can be taken to reduce environmental impact of retail deliveries. It needs to be accepted that some aspects will require investment by retailers, but that in many instances they benefit as well, both directly in cost terms and indirectly through customer recognition of their activities. 


\section{INSERT FIGURE 2 HERE}

There are other challenges that will undoubtedly face the retail logistics industry in the coming years. However we believe that looking forward, the key challenges are to make supply chains visible to aid efficiency and flexibility and to rethink existing and new activities to provide as green a solution as possible, based on sound practices and efficient operations. Making supply chains and logistics work in such a turbulent and different environment is a real challenge, compounded by the new realities of what is acceptable and possible. 


\section{References}

Aastrup, J. and Kotzab, H. (2010) 'Forty years of Out-of-Stock research - and shelves are still empty', International Review of Retail, Distribution and Consumer Research, 20, 147-164.

Agarwal, A., Shankar, R. and Tiwari, M.K. (2006) 'Modelling the metrics of lean, agile and leagile supply chain: an ANP-based approach', European Journal of Operational Research, 173, 211-225.

Aldridge, D. and Harrison, A. (2000) ' Implementing Agile Methods in Retail Supply Chains: a scenario for the future ', International Journal of Agile Manufacturing, 3, (2), 37-44.

Auton, B. (2005) What's Driving European Logistics? Presentation available at http://www.ciltuk.org.uk/download/Emerging Technologies in Retail Logistics . $\mathrm{pdf}$

Barnes, L. and Lea-Greenwood, G. (2006) 'Fast fashioning the supply chain: shaping the research agenda ', Journal of Fashion Marketing and Management, 10, (3), 259-271

Barratt, M. and Oke, A. (2007). 'Antecedents of supply chain visibility in retail supply chains: A resource-based theory perspective', Journal of Operations Management, 25, 1217 - 1233.

Bhardwaj, V. and Fairhurst, A. (2010) 'Fast fashion - responses to change in the fashion industry', International Review of Retail, Distribution and Consumer Research, 20, 165-173.

Birtwistle, G., Siddiqui, N. and Fiorito, S. (2003) 'Quick response: perceptions of UK fashion retailers ', International Journal of Retail \& Distribution Management, $31,(2), 118-128$

Bruce, M., Daly, L. and Towers, N. (2004) 'Lean or Agile: A solution for supply chain management in the textiles and clothing industry', International Journal of Operations \& Production Management, 23,( 2), 151-170

Burt, S.L., Dawson, J.A. and Larke, R. (2006) Inditex-Zara: rewriting the rules of apparel retailing, in Dawson, J.A., Larke R., and Mukoyama, M. (eds) Strategic Issues in International Retailing Routledge, London.

Canever, M.D., Van Trijp, H.C.M. and Beers, G. (2008) 'The emergent demand chain management: key features and illustration from the beef business', Supply Chain Management, 13, (2), 104-115.

Christopher, M. (2000) 'The Agile Supply Chain', Industrial Marketing Management, 29, 37-44. 
Christopher, M. and Peck, H. (2003) Marketing Logistics, Butterworth-Heineman, Oxford, $2^{\text {nd }}$ Edition.

Christopher, M., Lowson, R. and Peck, H. (2004) 'Creating agile supply chains in the fashion industry', International Journal of Retail and Distribution

Management, 32, (8), 367-376

Christopher, M. and Towill, D. (2001) 'An integrated model for the design of agile supply chains', International Journal of Physical Distribution and Logistics Management, 31, (4) , 235-46.

Cooper, M.C., Lambert, D.M., and Pagh, J.D. (1997) 'Supply chain management: more than a new name for logistics', The International Journal of Logistics Management, 8, (1), 1-14

Drucker, P. (1962) ' The Economy's Dark Continent', Fortune, April, 265-270.

Evans, W., Jacobs, H., Sparks, L., Denny, M., Webb, K. and Vilanova, M. (2009) Greening Retail: Volume 2 - Best Environmental Practices of Leading Retailers from around the world. CSCA: Ryerson, Toronto.

Fernie, J. (1990) Retail Distribution Management, Kogan Page, London.

Fernie, J. (1994) 'Quick Response: An International Perspective', International Journal of Physical Distribution \& Logistics Management, 24,(6), 38-46

Fernie, J. (1997) ' Retail change and retail logistics in the United Kingdom: past trends and future prospects', Service Industries Journal, 17,(3), 383-396

Fernie, J (2006) Retail Logistics, chapter 18 in Waters, D., Global Logistics: New Directions in Supply Chain Management, Fifth Edition, Kogan Page, London

Fernie, J. and Azuma, N. (2004) 'The changing nature of Japanese fashion. Can quick response improve supply chain efficiency?', European Journal of Marketing, 38, (7), 749-69.

Fernie, J. and Grant, D.B. (2008) 'On shelf availability: the case of a UK grocery retailer', The International Journal of Logistics Management, 19,(3), 293-308

Fernie, J., Pfab, F. and Marchant, C. (2000)' Retail Grocery Logistics in the UK', International Journal of Logistics Management, 11,( 2), 83-90.

Fernie, J. and Sparks, L. (1998) Logistics and Retail Management, Kogan Page, London.

Fernie, J. and Sparks, L. (2004) Logistics and Retail Management, Kogan Page, London, $2^{\text {nd }}$ Edition. 
Fernie, J and Sparks, L. (2009) Logistics \& Retail Management; emerging issues and challenges in the retail supply chain, Kogan Page: London , $3^{\text {rd }}$ Edition

Fiorito, S., May, E. and Straughn, K. (1995)' Quick response in retailing: components and implementation', International Journal of Retail \& Distribution Management, $23,(5), 12-2$

Foley, P., Alfonso, X., Brown, K, Palmer, A., Lynch, D. and Jackson, M. (2003) The Home Delivery Sector in the UK 1995 to 2010, De Montfort University / Freight Transport Association, Leicester.

Forza, C., Vinelli, A. (1997) 'Quick response in the textile-apparel industry and the support of information technologies', Integrated Manufacturing Systems, 8, (3), 125-36

Fraunhofer Institute (2002) Consumer Direct Logistics, ECR- Europe, Brussels.

Grant, D.B. and Fernie, J. (2008) 'Exploring out-of-stock and on-shelf availability in non-grocery, high street retailing', International Journal of Retail \& Distribution Management, 36,( 8), 661-672

Harrison, A., Christopher, M. and van Hoek, R. (1999) Creating the Agile Supply Chain, Institute of Logistics and Transport, Corby.

IMRG (2006) E-tail Delivery Cost Benefit Analysis. (www.imrg.org)

Jones, DT (2002) Rethinking the grocery supply chain, in Grievink J-W, Josten L and C Valk (eds) State of the Art in Food. Elsevier, Rotterdam. (Available from www.leanuk.org/articles.htm - downloaded 30.10.03).

Langabeer, J. and Rose, J. (2002) Creating Demand Driven Supply Chains. Chandos, Oxford.

Langley, C.J. (1986) 'The Evolution of the Logistics Concept', Journal of Business Logistics, 7(2), 1-13.

Lowson, B. King, R. and Hunter, A. (1999) Quick Response: managing the supply chain to meet consumer demand. Chichester, Wiley.

Mandeville, L. (2000) Prospects for Home Shopping in Europe, FT Management Report, Pearson, London.

Miniwatts Marketing Group (2010) World Internet Usage Statistics, MMG, Bogota, D.C. Colombia

Mason-Jones R, Naylor B and D.R. Towill (2000) 'Lean, agile or leagile? Matching your supply chain to the marketplace', International Journal of Production Research, 38, (17), 4061-4070 
Mees, M.D. (2000) 'The Place of the Food Industry in the Global E-commerce Universe: Ahold's Experience' paper presented to the CIES conference on 'Supply Chain for E-commerce and Home Delivery in the Food Industry', Berlin.

McClellan, J. (2003) 'Sweet Smell of Success' The Guardian, 4th September

McMichael, H., Mackay, D. and Altman, G. (2000) 'Quick response in the Australian TCF industry: a case study of supplier response', International Journal of Physical Distribution \& Logistics Management, 30, (7/8), pp.611-26

McKinnon, A.C. (1996) The Development of Retail Logistics in the UK: A Position Paper, Technology Foresight: Retail and Distribution Panel, Edinburgh, HeriotWatt University.

McKinnon, A.C. (2006) A short history of Green Logistics Research in the UK. Presentation at the launch of the Green Logistics Project, Birmingham, Available at www.greenlogistics.org (Downloaded 9.12.09)

McKinnon, A.C. and Tallam, D. (2003) 'Unattended Delivery to the Home: An Assessment of the Security Implications', International Journal of Retail and Distribution Management, 31, (1), 30-4

McKinnon, A.C. and Edwards, J. (2009) The Greening of Retail Logistics, chapter 12 (p 253-273) in Fernie. J. and Sparks, L (eds) Logistics and Retail Management, London, Kogan Page

Morrell, L. (2001) 'Flexible Zara holds lessons for slowcoach competitors ', Retail Week, pp.10

Nairn, G. (2003) 'Not Many happy Returns', Financial Times, 5th February.

Naylor, J.B., Naim, M.M. and Berry, D. (1997) 'Leagility: integrating the lean and agile manufacturing paradigm in the total supply chain', International Journal of Production Economics, 62,107 -118.

Nockold, C. (2001) 'Identifying the real costs of home delivery', Logistics \& Transport Focus, 3, (10), 70-71.

Oke, A. and Gopalakrishnan, M. (2009) 'Managing disruptions in supply chains: A case study of a retail supply chain', International Journal Production Economics, $118,168-174$.

Punakivi, M. and Tanskanen, K. (2002) 'Increasing the cost efficiency of efulfilment using shared reception boxes', International Journal or Retail \& Distribution Management, 30, (10), 498-507. 
Smith, D.L.G. (2006) The Role of Retailers as Channel Captains in Retail Supply Chain Change: the example of Tesco. Unpublished PhD Thesis, University of Stirling.

Smith, D.L.G. and Sparks, L. (1993) ' The transformation of physical distribution in retailing: the example of Tesco plc', International Review of Retail, Distribution and Consumer Research, 3, 35-64.

Smith, D.L.G. and Sparks, L. (2004) Logistics in Tesco: past, present and future, p101-120 (Chapter 6) of Fernie, J. and Sparks, L. (eds) Logistics and Retail Management. Kogan Page, London, $2^{\text {nd }}$ Edition.

Smith, D.L.G. and Sparks, L. (2009) Tesco's supply chain management, p143-171 (Chapter 7) of Fernie, J. and Sparks, L. (eds) Logistics and Retail Management. Kogan Page, London, 3rd Edition.

Sparks, L. (1986) 'The changing structure of distribution in retail companies', Transactions of the Institute of British Geographers, 11(2), 147-154.

Sparks, L. (1998) The Retail Logistics Transformation, Chapter 1 (p1-22) of Fernie, J. and Sparks, L. (eds) (1998). Logistics and Retail Management. London, Kogan Page.

Towill, D. and Christopher, M. (2002) 'The Supply Chain Strategy Conundrum: to be lean or agile or to be lean and agile?', International Journal of Logistics, 5,(3), 299-309.

Verdict Research Consultancy (2008) 'No sign of an e-tail slowdown', Press Release, April 16.

Walters, D. (2006a) 'Effectiveness and efficiency: the role of demand chain management', International Journal of Logistics Management, 17, 75-94.

Walters, D. (2006b) 'Demand chain effectiveness - supply chain efficiencies', Journal of Enterprise Information, 19, 246-51.

Walters, D. and Rainbird, M. (2004) 'The demand chain as an integral component of the value chain', Journal of Consumer Marketing, 21, 465-75.

Williams, D.E. (2009) The evolution of e-tailing, International Review of Retail, Distribution and Consumer Research, 19, 219-249.

Womack, J. P., Jones, D. and Roos, D. (1990) The Machine that Changed the World: The Story of Lean Production, Harper-Collins, New York.

Womack, J.P. and Jones, D.T. (2005) Lean Solutions. Simon and Schuster, London.

Zentes, J., Marschett, D. and Schramm-Klein, H. (2007) Strategic Retail

Management, Sainsbury's, Gabler: Weisbaden., 286-95. 
Xing, Y. and Grant, D. (2006) 'Developing a Framework for Measuring Physical Distribution Service Quality of Multi-channel and 'Pure Player' Internet

Retailers', International Journal of Retail \& Distribution Management, 34, (4/5), 278-289. 
Table 1: Comparison of lean, agile, and leagile supply chains

\begin{tabular}{|c|c|c|c|}
\hline $\begin{array}{l}\text { Distinguishing } \\
\text { attributes }\end{array}$ & $\begin{array}{l}\text { Lean supply } \\
\text { chain }\end{array}$ & $\begin{array}{l}\text { Agile supply } \\
\text { chain }\end{array}$ & $\begin{array}{l}\text { Leagile supply } \\
\text { chain }\end{array}$ \\
\hline Market demand & Predictable & Volatile & $\begin{array}{l}\text { Volatile and } \\
\text { unpredictable }\end{array}$ \\
\hline Product variety & Low & High & Medium \\
\hline Product life cycle & Long & Short & Short \\
\hline Customer drivers & Cost & $\begin{array}{l}\text { Lead-time and } \\
\text { availability }\end{array}$ & Service level \\
\hline Profit margin & Low & High & Moderate \\
\hline Dominant costs & Physical costs & $\begin{array}{l}\text { Marketability } \\
\text { costs }\end{array}$ & Both \\
\hline Stock out penalties & $\begin{array}{l}\text { Long term } \\
\text { contractual }\end{array}$ & $\begin{array}{l}\text { Immediate and } \\
\text { volatile }\end{array}$ & $\begin{array}{l}\text { No place for stock } \\
\text { out }\end{array}$ \\
\hline Purchasing policy & Buy goods & Assign capacity & $\begin{array}{l}\text { Vendor managed } \\
\text { inventory }\end{array}$ \\
\hline $\begin{array}{l}\text { Information } \\
\text { enrichment }\end{array}$ & Highly desirable & Obligatory & Essential \\
\hline $\begin{array}{l}\text { Forecast } \\
\text { mechanism }\end{array}$ & Algorithmic & Consultative & Both/either \\
\hline Typical products & Commodities & Fashion goods & $\begin{array}{l}\text { Product as per } \\
\text { customer demand }\end{array}$ \\
\hline $\begin{array}{l}\text { Lead time } \\
\text { compression }\end{array}$ & Essential & Essential & Desirable \\
\hline Eliminate muda & Essential & Desirable & Arbitrary \\
\hline $\begin{array}{l}\text { Rapid } \\
\text { reconfiguration }\end{array}$ & Desirable & Essential & Essential \\
\hline Robustness & Arbitrary & Essential & Desirable \\
\hline Quality & Market qualifier & Market qualifier & Market qualifier \\
\hline Cost & Market winner & Market qualifier & Market winner \\
\hline Lead-time & Market qualifier & Market qualifier & Market qualifier \\
\hline Service level & Market qualifier & Marker winner & Market winner \\
\hline
\end{tabular}

Source: Agarwal et al (2006), p212. 
Table 2: Supply and Demand Chain Comparison

\begin{tabular}{|c|c|}
\hline Supply chain & Demand chain \\
\hline Efficiency focus; cost per item & $\begin{array}{l}\text { Effectiveness focus; customer-focused, } \\
\text { product-market fit }\end{array}$ \\
\hline Processes are focused on execution & $\begin{array}{l}\text { Processes are focused more on } \\
\text { planning and delivering value }\end{array}$ \\
\hline Cost is the key driver & $\begin{array}{l}\text { Cash flow and profitability are the key } \\
\text { drivers }\end{array}$ \\
\hline $\begin{array}{l}\text { Short-term oriented, within the } \\
\text { immediate and controllable future }\end{array}$ & $\begin{array}{l}\text { Long-term-oriented, within the next } \\
\text { planning cycles }\end{array}$ \\
\hline $\begin{array}{l}\text { Typically the domain of tactical } \\
\text { manufacturing and logistics personnel }\end{array}$ & $\begin{array}{l}\text { Typically the domain of marketing, } \\
\text { sales and strategic operations } \\
\text { managers }\end{array}$ \\
\hline $\begin{array}{l}\text { Focuses on immediate resource and } \\
\text { capacity constraints }\end{array}$ & $\begin{array}{l}\text { Focuses on long term capabilities, not } \\
\text { short term constraints }\end{array}$ \\
\hline $\begin{array}{l}\text { Historical focus on operations planning } \\
\text { and controls }\end{array}$ & $\begin{array}{l}\text { Historical focus on demand } \\
\text { management and supply chain } \\
\text { alignment }\end{array}$ \\
\hline
\end{tabular}

Source: Langabeer and Rose (2001) in Walters (2006b) 
Figure 1: Classification of Unattended Delivery Systems

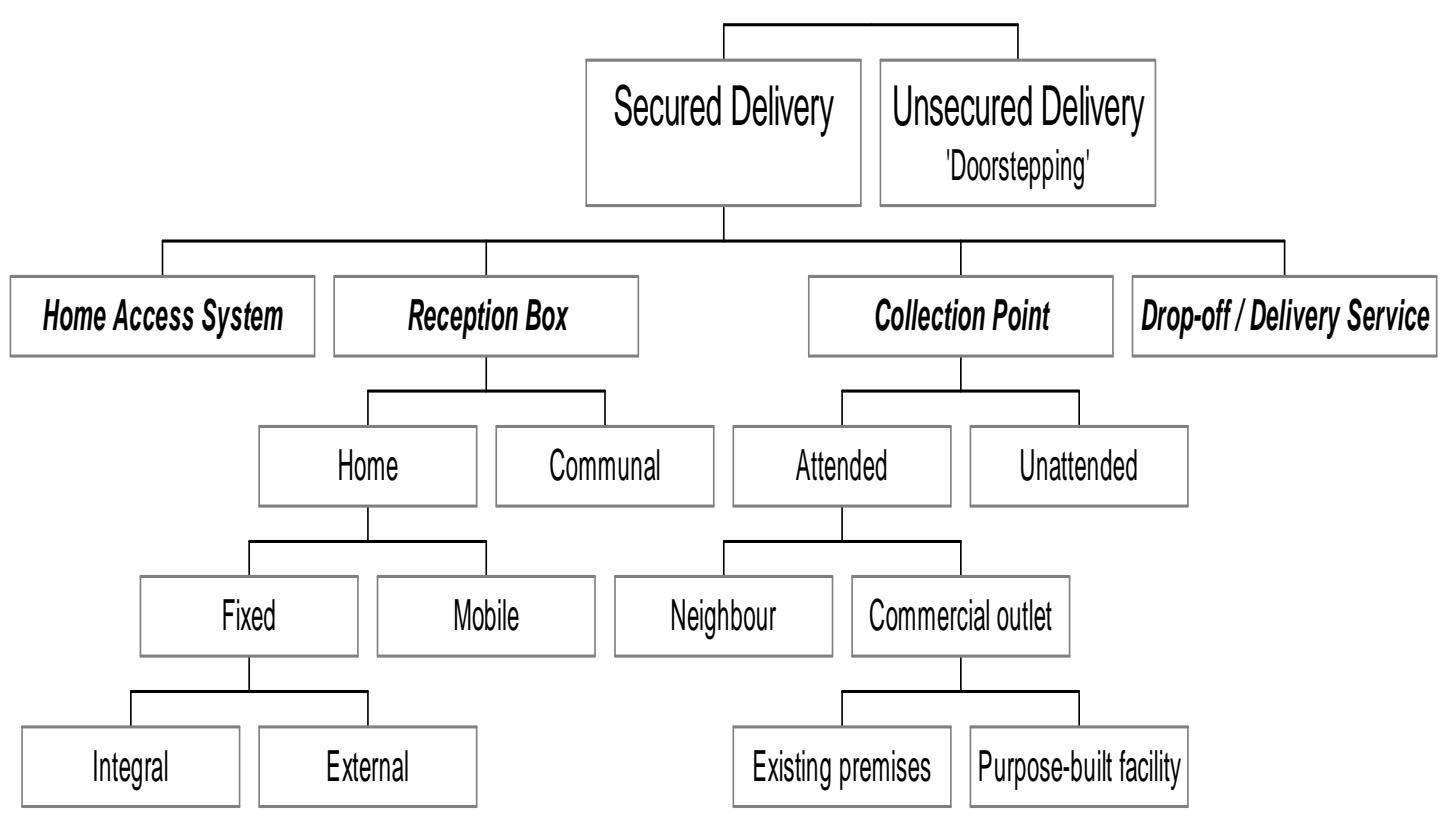

Source: McKinnon and Tallam (2003) 
Figure 2: Framework for Analysing the Environmental Impact of Retail Deliveries

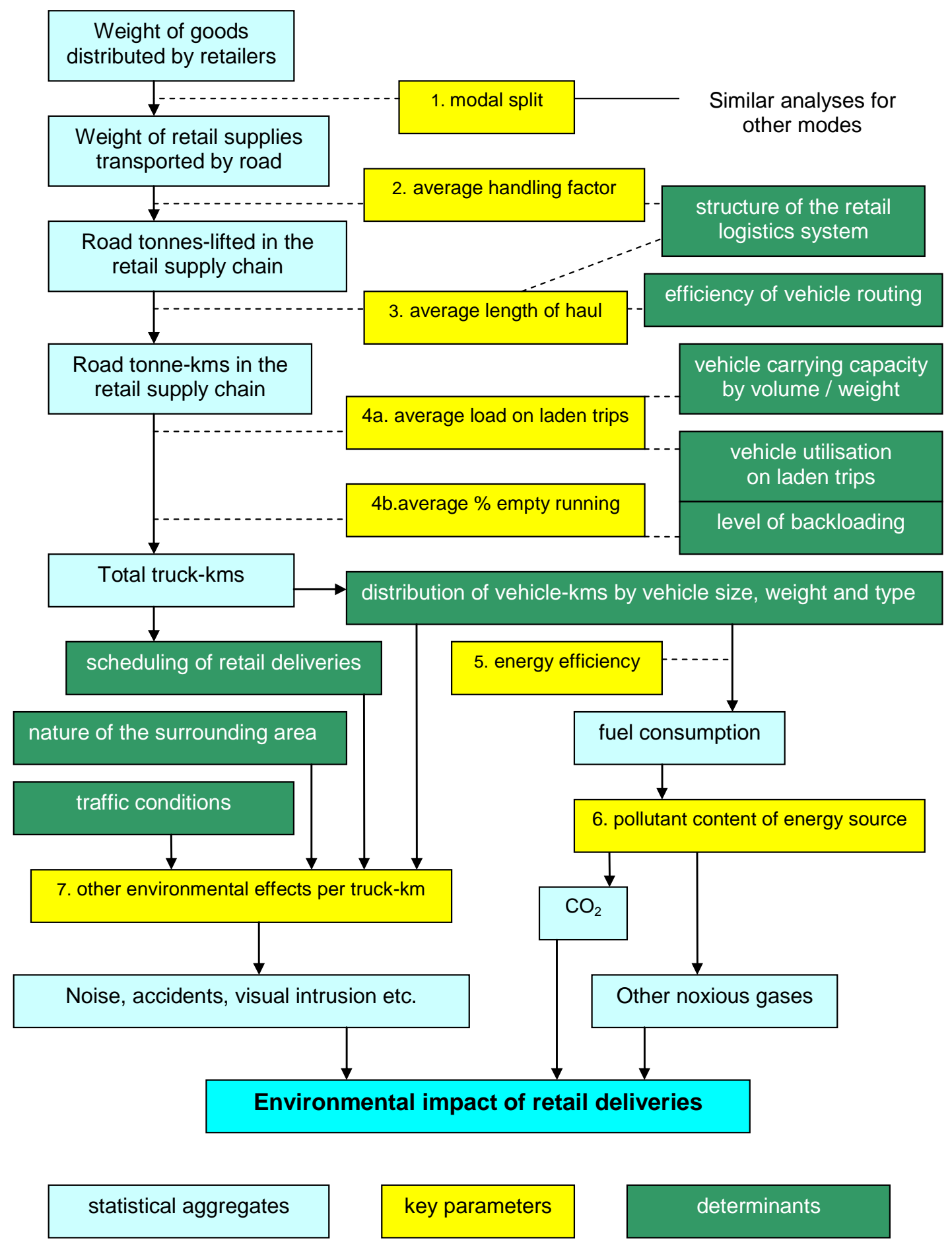

Source : McKinnon and Edwards, 2009 